\title{
Bacteriological and histological studies of the small intestine of rats treated with mecamylamine
}

\author{
J. M. S. DIXON AND J. W. PAULlEY \\ From the Public Health Laboratory, Woodbridge Road East, Ipswich, \\ and the Ipswich and East Suffolk Hospital
}

EDITORIAL SYNOPSIS Rats were injected intraperitoneally with mecamylamine (Inversine) in doses that were believed to have reduced peristaltic activity in the small intestine. Large numbers of Escherichia coli were present throughout the lumen of the small intestine of animals treated for two or three days and killed within three hours of the last dose of the drug. Histological changes in the small intestinal mucosa of these animals included an increase in the number of goblet cells and shortening and thickening of the villi. Bacteria invaded the intestinal wall of some of the animals. Animals killed 24 hours after the last dose of the drug showed no significant change from the normal controls.

The findings support the hypothesis that bacteria are removed mechanically from the normal small intestine by peristalsis. Certain of the histological changes are similar to those seen in the small intestine in malabsorptive conditions in man and the relationship between hypomotility, the bacterial population, and malabsorption is discussed.

The early observation of Cushing and Livingood (1900) which suggested that the normal small intestine contains very few bacteria has now been confirmed by many workers using the technique of direct aspiration described by Blacklock, Guthrie, and Macpherson (1937) and developed by Cregan and Hayward (1953). Experiments with rats have suggested that rapid and effective removal by normal peristaltic action is the major reason for the absence of bacteria in the small gut (Dixon, 1960). Clinical observations support this suggestion, for patients with disease of the small intestine in which hypomotility is likely to occur often benefit greatly from antibiotic treatment, indicating that an abnormal bacterial flora was contributing to the illness. This experience has been reported in Whipple's disease (Paulley, 1952a; Haex and Beek, 1955; Chears, Hargrove, Verner, Smith, and Ruffin, 1961), 'indigenous sprue' (Renner, 1952), tropical sprue (French, Gaddie, and Smith, 1956), in six of 15 patients with gluten-resistant idiopathic steatorrhoea (Crane and French, quoted by French, 1961), and in the various forms of loop syndrome, including jejunal diverticulosis (Dick, 1955) and postgastrectomy steatorrhoea (Wirts, Goldstein, Calaresu, Kramer, and Concannon, 1959; Goldstein, Wirts, and Kramer, 1961).

Studies in man designed to show contamination of the upper small intestine with faecal organisms have been mainly negative in coeliac disease and tropical sprue. They have been positive in jejunal diverticulosis (Girdwood and Doig, 1957), in the afferent loop after gastrectomy (Goldstein et al., 1961), and in isolated cases of idiopathic steatorrhoea by needle aspiration at laparotomy (Girdwood, 1959; Paulley, 1959). French (1961) has made the suggestion that some of the negative findings to date may be related to the fact that a fasting state was usual at the time of sampling.

Histological evidence of mucosal erosions and lowgrade inflammation in idiopathic steatorrhoea, including in some instances pus cells and bacteria in apposition to the jejunal epithelium, has been advanced from time to time by one of us (Paulley, $1949,1952 b, 1954 a, 1959)$. In cases of loop syndrome the bacterial population was very dense and the structure of the villi was relatively well preserved; in idiopathic steatorrhoea (Paulley, 1961) bacteria were fewer on a mucosa where normal architecture was greatly disturbed. Recently Strauss, Donaldson, and Gardner (1961) have demonstrated great increases in bacterial flora and activity in surgicallyproduced diverticulae of the small intestine of rats, but we have found no reports on drug-induced stasis without anatomical interference.

The present work records experiments in which 
rats were injected with mecamylamine (Inversine) in doses which almost certainly reduced the propulsive activity of the small intestine. The bacteriological and histological changes noted in the small gut are believed to have resulted from this druginduced stasis.

\section{METHODS}

Adult albino rats weighing approximately $200 \mathrm{~g}$. were used. Intraperitoneal injections of mecamylamine (Inversine) were given for periods varying from two to 20 days. The drug was given twice daily, the total daily dosage being between 12 and $20 \mathrm{mg} . / \mathrm{kg}$. The latter dose was given for not more than three days, as it was obviously near the limit of tolerance. Control animals were from the same group of rats but were not injected. Solid food was removed from the cages four hours before the animals were killed. Rats were killed, either within three hours of the last injection or the following day, by a blow on the back of the neck. The abdomen was opened immediately and two $1 \mathrm{~cm}$. lengths of the small intestine were removed, opened longitudinally and immediately immersed with agitation in $10 \%$ formol saline for subsequent histological examination by Gram and haematoxylin and eosin stains. The remainder of the small intestine was removed from the animal and subdivided into three sections of approximately equal length. Each section, termed upper, middle, or lower small intestine, was opened longitudinally and placed in a sterile screw-capped bottle containing $10 \mathrm{ml}$. Ringer's solution. The bottles were then agitated mechanically for $\mathbf{2 0}$ minutes in a Kahn shaker at $\mathbf{2 7 0}$ oscillations per minute. Serial ten-fold dilutions of the fluid were made in quarter-strength Ringer's solution and viable bacterial counts made on horse blood agar and MacConkey agar by the method of Miles and Misra (1938). The plates were examined after overnight incubation and the number of bacteria present in the sections of the small intestine calculated.

\section{RESULTS}

Thirteen treated rats and four control animals were examined.

BACTERIOLOGY The coliform counts of the small intestinal sections of treated and control rats are summarized in the table. All regions of the small intestine of rats given mecamylamine for three days or less and killed during treatment, i.e., within three hours of the last dose, contained many more coliforms than those of the control rats. Moderate dilatation of the small intestine was noted at postmortem examination in most of these animals, and the gut often contained watery fluid. Animals treated with similar doses for longer periods and killed within three hours of the last injection showed little increase in flora and the bowel was not noticeably dilated. Three rats from different batches given mecamylamine for three days, but killed 24 hours after the last mecamylamine injection, also showed little abnormality in the small intestinal flora.

Total viable counts as determined on the blood agar plates are not quoted because the predominance of coliforms on the plates from treated animals made it difficult to enumerate organisms on this medium. Representative colonies of the coliforms were examined biochemically and were found to be Escherichia coli. None of the coliforms isolated was agglutinated by a polyvalent serum containing antibodies to the serotypes of Esch. coli associated with infantile gastroenteritis.

HISTOLOGY Sections taken from the approximate points of junction of the upper and lower thirds of the small gut with the middle third were examined.

Seven rats killed during mecamylamine treatment showed a similar, but abnormal, histological picture. These rats were from different experiments but all were killed within three hours of the last dose of courses of mecamylamine given over periods of two or three days. The dosage of drug given to these animals and the bacteriological findings are indicated in the table. There was shortening and thickening of the villi of these animals (Fig. 1) compared with the control animals (Fig. 2) and a very striking increase in the size and number of goblet cells in the upper small intestine (Fig. 3) when compared with untreated rats (Fig. 4). Goblet cell counts in a standard

TABLE

EFFECT OF INTRAPERITONEAL INJECTIONS OF MECAMYLAMINE ON THE COLIFORM POPULATION AND HISTOLOGY OF RAT SMALL INTESTINE

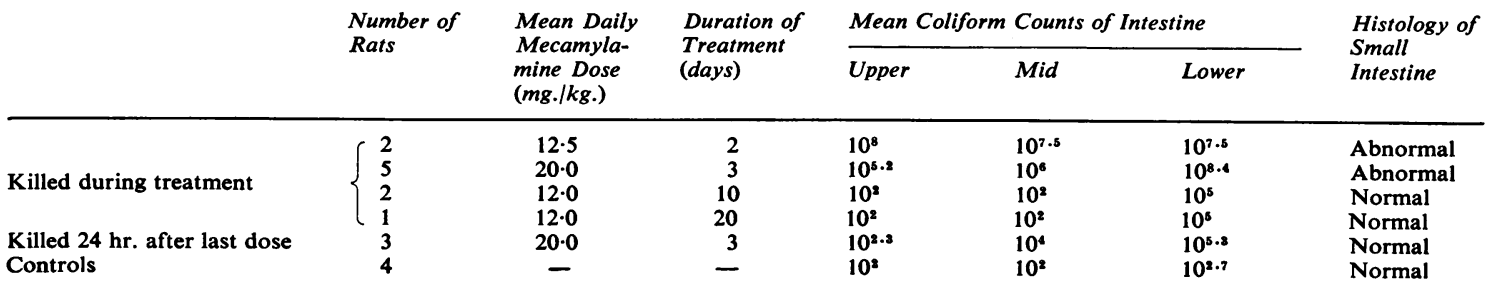




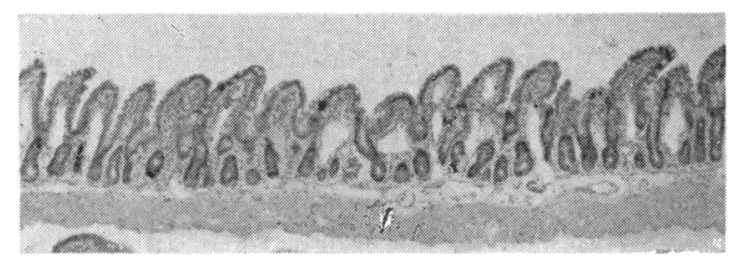

FIG. 1

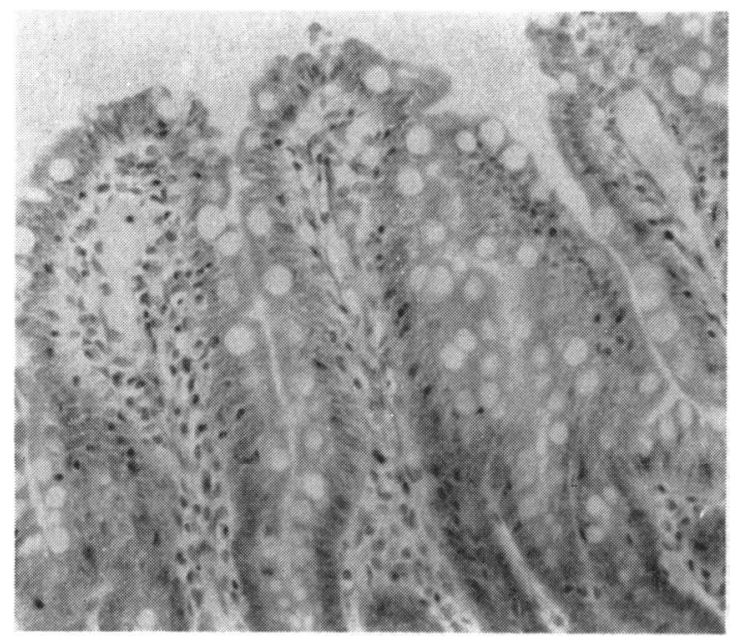

FIG. 3

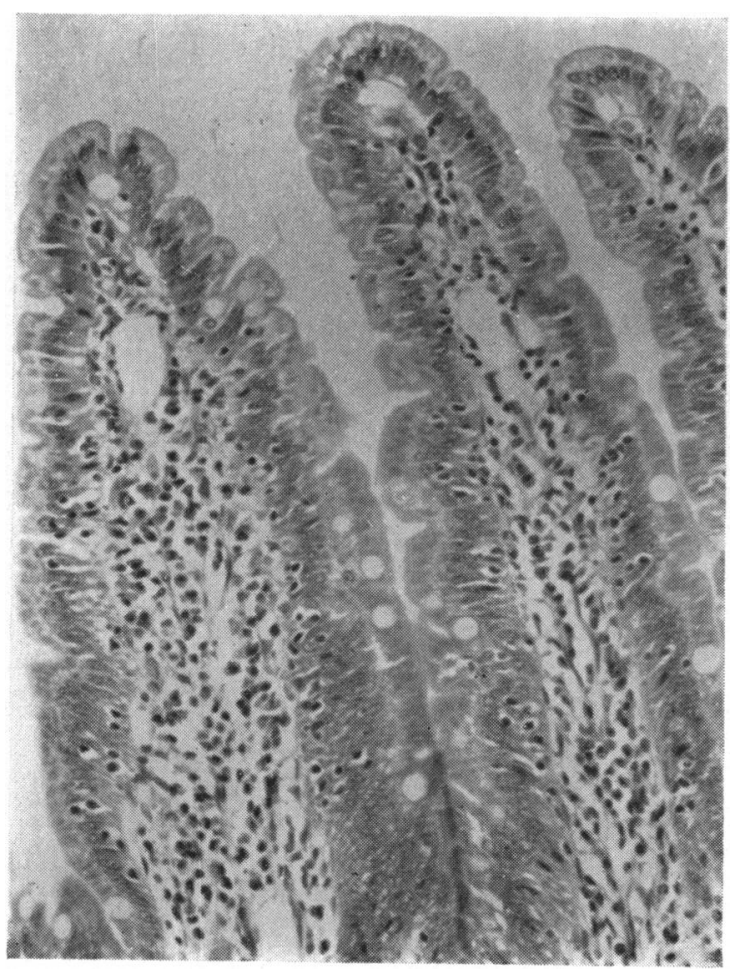

FIG. 4

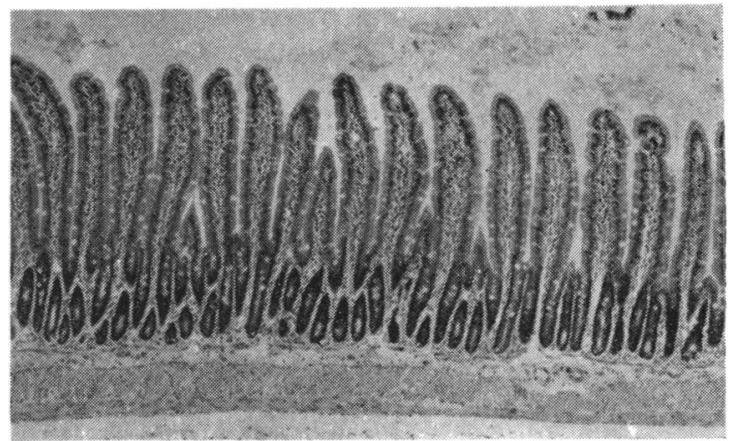

FIG. 2

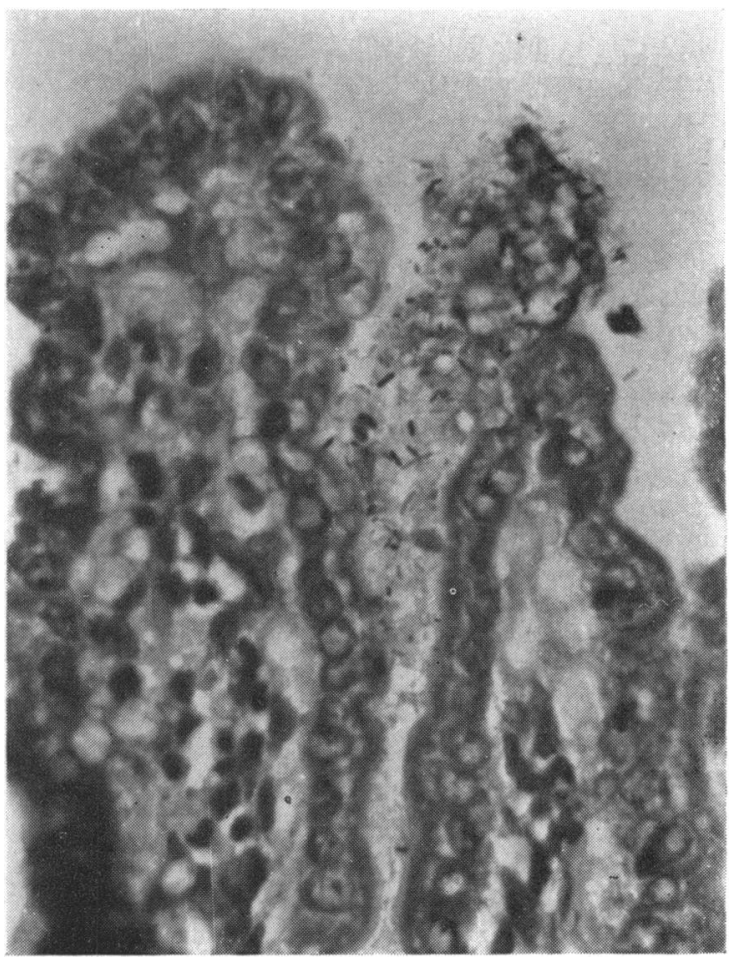

FIG. 5

FIG. 1. Rat: Upper small intestine of animal killed one hour after last injection of a course of mecamylamine; $\times$ 37. Haematoxylin and eosin.

FIG. 2. Rat: Upper small intestine of untreated animal; $\times$ 37. Haematoxylin and eosin.

FIG. 3. Rat: Upper small intestine of animal killed during treatment with mecamylamine; numerous enlarged goblet cells and swollen villi; $\times 240$. Haematoxylin and eosin.

FIG. 4. Rat: Upper small intestine of untreated animal; $\times$ 240. Haematoxylin and eosin.

FIG. 5. Rat: Jejunal mucosa during mecamylamine treatment; bacteria present in intervillous space; $\times 440$. Gram. 
field were made and the treated animals showed increases of 50 to $100 \%$ over the controls; the goblet cells were often much larger in the treated animals. Many bacteria were seen in apposition to the villous epithelium, probably enmeshed in a layer of mucus (Fig. 5). The organisms were predominantly Grampositive rods, despite the high coliform counts obtained in the viable counts on these animals. This paradox may be due to the facility with which Gramnegative bacteria are said to be washed off slides during staining procedures unless special precautions are taken (Petuely and Lindner, 1960). Sections from two of the rats showed bacterial invasion of the wall of the lower small intestine, bacteria being present in the submucosal lymphatics and in the muscular layer of the gut. The organisms were mainly short Gram-positive rods, although the lumen contained masses of bacteria morphologically resembling clostridia and coliforms. Two further rats that had been injected with doses identical with those given to the latter two animals were left to be killed the next day, but they died overnight and so are not included in this series. It is possible that these animals died from similar invasion of the intestinal wall.

In marked contrast to the changes noted in animals killed within three hours of the last injection, three rats killed 24 hours after completion of threeday courses of mecamylamine similar to those received by the other rats showed no obvious histological changes. There was also no abnormality in three rats that were treated for 10 or 20 days even though they were killed within three hours of the last dose.

\section{DISCUSSION}

In these studies mecamylamine injected intraperitoneally in rats resulted in the appearance of a large bacterial population in the lumen of the small intestine within 48 hours. Parallel changes were observed in the intestinal mucosa, especially with regard to increased goblet cell activity. This increased mucous activity may have been due to the effect of bacteria on a mucosa unaccustomed to their presence, or to the irritant effect of food or its breakdown products. In contrast, but excepting the rats which developed bacterial invasion of the wall of the lower small gut, was the rapid return to the normal state, both bacteriologically and histologically, if as short a time as $\mathbf{2 4}$ hours was allowed to elapse between giving the last dose of mecamylamine and killing the rat. Such rapid mucosal recovery is in keeping with the recent striking experiments of Fell, Boyne, and Cuthbertson (1961) in which regeneration of shed small intestinal epithelium was reported to occur within two or three hours.
No marker was used in the present study to prove that the small intestinal flow was slowed by the doses of drug used. Mecamylamine is not only a ganglionic blocking agent, however, but also directly depresses activity of intestinal smooth muscle (Bennett, Tyler, and Zaimis, 1957). Gastro-intestinal motility in mice is inhibited by intraperitoneal mecamylamine in doses of 1 to $4 \mathrm{mg}$. $/ \mathrm{kg}$. (Zawoiski and Stone, 1962), a dose much smaller than that used in rats in the present work. Paralytic ileus has occurred in human patients during treatment with mecamylamine (Grant and Boyd, 1957). The doses of the drug used in the present study were near the limit of tolerance of the rat (Milne, Rowe, Somers, Muehrcke, and Crawford, 1957), and it is almost certain, therefore, that a great decrease in peristaltic activity resulted from the intraperitoneal injections of mecamylamine. A repetition of this work, using a drug acting by a mechanism different from that of mecamylamine, would be valuable to confirm that the changes we noted were due to intestinal stasis and were not related to other actions of the drug.

The results support the view that peristaltic action is one of the major reasons for the scarcity of bacteria in the normal small intestine; this muscular activity may be regarded as a defence against invasion by bacteria of an area where their presence seems to be deleterious. The finding of no abnormalities in rats that had been treated for 10 and 20 days was possibly due to the development of tolerance to the drug, but no attempt was made to prove this. The bacterial invasion of the gut wall in two of the treated rats may have been due to the conditioning effect of other factors such as the resident colonic flora at the time of the experiment, but also suggests that the mecamylamine dosage was near the limit of tolerance. Points arise from the work which may be relevant to the understanding of the causes of malabsorption states in man and to the interpretation of microanatomical changes that have been observed in these states. The present study suggests that increased goblet cell activity should receive more attention than hitherto. It is particularly obvious in the jejunal mucosa in some examples of post-gastrectomy malabsorption and in cases of idiopathic steatorrhoea. It may be an indication of bacterial or chemical irritation in the lumen in these conditions. The experiments also showed the rapidity with which bacterial invasion of the upper small gut may follow hypomotility, and the speed with which the organisms disappear when peristalsis returns to normal. It is not difficult to envisage the occurrence in man of similar events to those described, some equally transient, some recurrent, some benign, but some more severe in their effects. Physical shock has long been suspected to predispose to the extreme event 
of pseudomembraneous enterocolitis (Penner and Bernheim, 1939; Bruce, 1954); that emotional shock may do so is more revolutionary (Paulley, 1954b). Lesser paralytic effects resulting from sustained fear, biochemical changes, metabolic and ingested poisons, and any disorder of the neuromusculature, all appear to have a disease potential in the small gut by permitting an abnormal bacterial population and perhaps mucosal damage.

We are indebted to Dr. Clement A. Stone, Director of the Merck Institute for Therapeutic Research, for valuable advice. We are grateful to Mr. J. L. Durrant for technical assistance and we thank Dr. A. C. Thackray of the Bland-Sutton Institute of Pathology, Middlesex Hospital, for taking the photomicrographs and Dr. J. J. F. Merry of Messrs. Merck Sharp \& Dohme for the supply of Inversine.

\section{REFERENCES}

Bennett, G., Tyler, C., and Zaimis, E. (1957). Mecamylamine and its mode of action. Lancet, 2, 218-222.

Blacklock, J. W. S., Guthrie, K. J., and Macpherson, I. (1937). A study of the intestinal flora of children. J. Path. Bact., 44, 321-335.

Bruce, J. (1954). Post-operative necrosis of the intestinal mucous membrane. Gastroenterologia (Basel), 81, 74-80.

Chears, W. C. Jr., Hargrove, M. D. Jr., Verner, J. V. Jr., Smith, A. G., and Ruffin, J. M. (1961). Whipple's disease; a review of twelve patients from one service. Amer. J. Med., 30, 226-234.

Cregan, J., and Hayward, N. J. (1953). The bacterial content of the healthy human small intestine. Brit. med. J., 1, 1356-1359.

Cushing, H., and Livingood, L. E. (1900). Experimental and surgical notes upon the bacteriology of the upper portion of the alimentary canal, with observations on the establishment there of an amicrobic state as a preliminary to operative procedures on the stomach and small intestine. Johns Hopk. Hosp. Rep., 9, 543-591.

Dick, A. P. (1955). Association of jejunal diverticulosis and steatorrhoea. Brit. med. J., 1, 145-148.

Dixon, J. M. S. (1960). The fate of bacteria in the small intestine. J. Path. Bact., 79, 131-140.

Fell, B. F., Boyne, R., and Cuthbertson, D. P. (1961). Intestinal lesions following histamine liberation in the rat. Ibid., 82, 445-452.
French, J. M. (1961). Problems raised by the treatment of steatorrhoea with antibacterial drugs. Postgrad. med. J., 37, 259-267.

French, J. M., Gaddie, R., and Smith, N. M. (1956). Tropical sprue. A study of seven cases and their response to combined chemotherapy. Quart. J. Med., 25, 333-351.

Girdwood, R. H. (1959). Personal communication.

areas of small intestine: the demonstration in vitro of the uptake of vitamin $B_{12}$ by bacteria isolated from such loops. Scot. med. J., $2,313$.

Goldstein, F., Wirts, C. W., and Kramer, S. (1961). The relationship of afferent limb stasis and bacterial fora to the production of postgastrectomy steatorrhoea. Gastroenterology, 40, 47-54.

Grant, A. P., and Boyd, J. S. (1957). Mecamylamine ileus as a surgical emergency. Lancet, 1, 713-715.

Haex, A. J. Ch., and Beek, C. van (1955). Behandeling van de ziekte van Whipple met chemotherapeutica en antibiotica. Ned. $T$. Geneesk., 99, 2770-2776.

Miles, A. A., and Misra, S. S. (1938). The estimation of the bactericidal power of the blood. J. Hyg. (Lond.), 38, 732-748.

Milne, M. D., Rowe, G. G., Somers, K., Muehrcke, R. C., and Crawford, M. A. (1957). Observations on the pharmacology of mecamylamine. Clin. Sci., 16, 599-614.

Paulley, J. W. (1949). Whipple's disease (intestinal lipodystrophy). Gastroenterologia (Basel), 75, 32-33.

- (1952a). A case of Whipple's disease (intestinal lipodystrophy). Gastroenterology, 22, 128-133.

- (1952b). Discussion, coeliac disease and idiopathic steatorrhoea Trans, roy. Soc. trop. Med. Hyg., 46, 594-595.

- - (1954a). Observations on the aetiology of idiopathic steatorrhoea : jejunal and lymph-node biopsies. Brit. med. J., 2, 1318-1321.

- (1954b). Discussion on post-operative necrosis of the intestinal mucous membrane. Gastroenterologia (Basel), 81, 79.

- (1959). Jejunal mucosa in idiopathic steatorrhoea. Lancet, 2, 646-648.

- (1961). The nature of the mucosal lesion in idiopathic steatorrhoea and coeliac disease. Proc. int. Cong. Gastroenterology, Leiden, 1960, 183-185.

Penner, A., and Bernheim, A. I. (1939). Acute postoperative enterocolitis; a study on the pathologic nature of shock. Arch. Path., 27, 966-983.

Petuely, F., and Lindner, G. (1960). Kritische Untersuchungen über die Darmflora. 1. Mitteilung: Die Verschiebung der Keimrelation im gramgefärbten Ausstrich. Zbl. Bakt. I (Orig), 177, 332-339.

Renner, D. (1952). Erfolgreiche Aureomycinbehandlung bei einheimischer Sprue. Med. Klin., 47, 1659.

Strauss, E. W., Donaldson, R. M. Jr., and Gardner, F. H. (1961). A relationship between intestinal bacteria and the absorption of vitamin B12 in rats with diverticula of the small bowel. Lancet, 2, 736-738.

Wirts, C. W. F., Goldstein, F., Calaresu, F. R., Kramer, S., and Concannon, J. (1959). The mechanism of absorption of radioactive labeled fat. Proc. Wld. Cong. Gastroenterology, Washington, 1958, 451-456.

Zawoiski, E. J., and Stone, C. A. (1962). Personal communication. 